\title{
Governance, Government, and the Search for New Provider Models
}

\section{Richard B. Saltman ${ }^{1 *}$, Antonio Duran ${ }^{2}$}

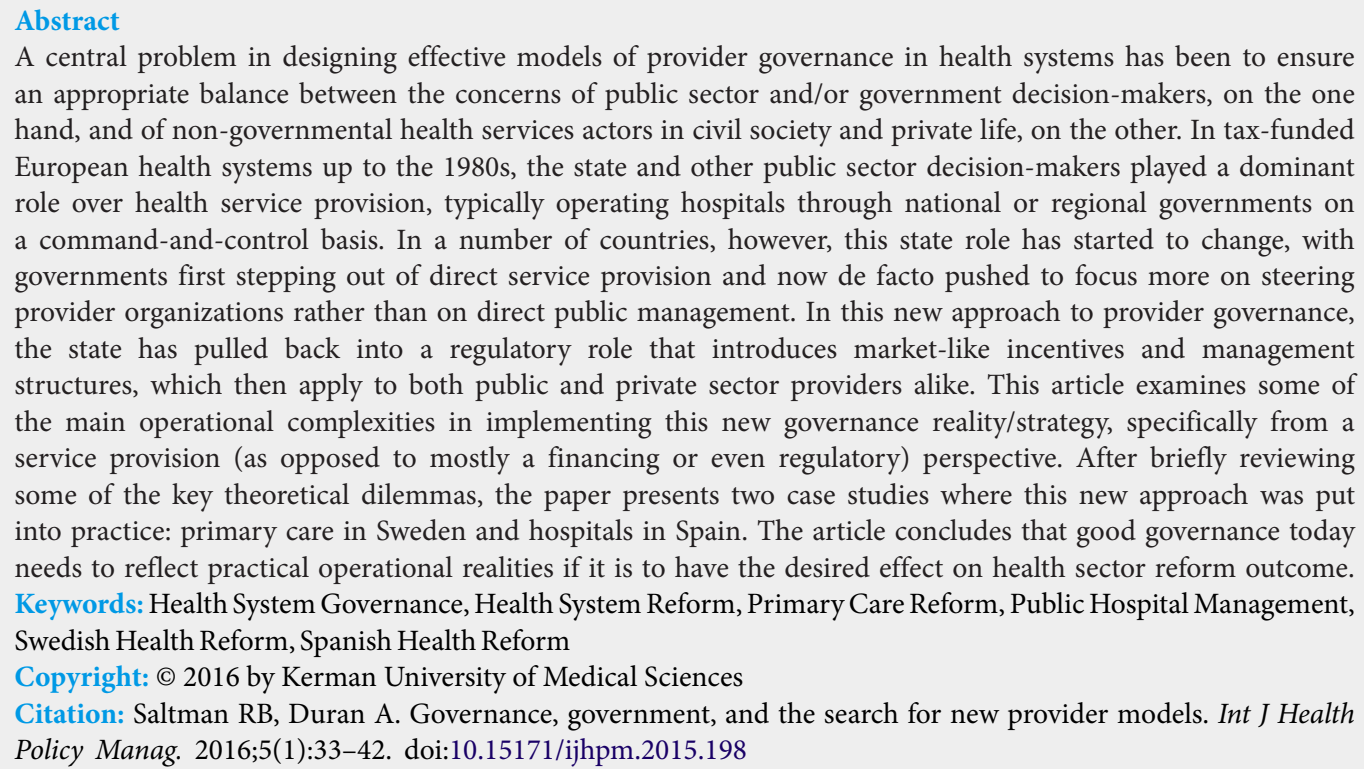

A central problem in designing effective models of provider governance in health systems has been to ensure an appropriate balance between the concerns of public sector and/or government decision-makers, on the one hand, and of non-governmental health services actors in civil society and private life, on the other. In tax-funded European health systems up to the 1980s, the state and other public sector decision-makers played a dominant role over health service provision, typically operating hospitals through national or regional governments on a command-and-control basis. In a number of countries, however, this state role has started to change, with governments first stepping out of direct service provision and now de facto pushed to focus more on steering provider organizations rather than on direct public management. In this new approach to provider governance, the state has pulled back into a regulatory role that introduces market-like incentives and management structures, which then apply to both public and private sector providers alike. This article examines some of the main operational complexities in implementing this new governance reality/strategy, specifically from a service provision (as opposed to mostly a financing or even regulatory) perspective. After briefly reviewing some of the key theoretical dilemmas, the paper presents two case studies where this new approach was put into practice: primary care in Sweden and hospitals in Spain. The article concludes that good governance today needs to reflect practical operational realities if it is to have the desired effect on health sector reform outcome. Keywords: Health System Governance, Health System Reform, Primary Care Reform, Public Hospital Management, Swedish Health Reform, Spanish Health Reform

Copyright: $\odot 2016$ by Kerman University of Medical Sciences

Citation: Saltman RB, Duran A. Governance, government, and the search for new provider models. Int J Health Policy Manag. 2016;5(1):33-42. doi:10.15171/ijhpm.2015.198

\section{Article History:}

Received: 29 June 2015

Accepted: 29 October 2015

ePublished: 3 November 2015
*Correspondence to:

Richard B. Saltman

Email: rsaltma@emory.edu

\section{Introduction}

Strengthening governance in the health services provider sector is a complex endeavor. It involves balancing the multiple conflicting logics and interests of patients, staff, citizens, and politicians as well as other stakeholders, all while the focus on improving access, quality and safety, and on health outcomes, responsiveness and system performance is not lost.

One of the central dilemmas in designing new provider models of governance has been to re-think the appropriate decision-making balance between the public sector and/or government, on the one hand, and the various actors in civil society and private non-governmental life, on the other. While in Europe (the case of the United States, Canada, or Asian Organisation for Economic Co-operation and Development [OECD] countries is slightly different) this shift in thinking has been underway in social health insurance-based health systems as well (particularly the Netherlands), it has been most apparent in the predominantly tax-funded health systems of Northern and Southern Europe, as well as - since 1991 - in the hybrid state-run social insurance models that have emerged in Central Europe. ${ }^{1}$

Up to the 1970s and 1980s, the state and other public sector decision-makers in tax-funded health systems played a dominant role over health service provision, typically operating hospitals through national or regional governments on a command-and-control basis. More recently, however, this role has changed in a growing number of countries, with states now focusing more on steering rather than on direct public management of health sector provider organizations. In this new approach, the state has pulled back into a supervisory and regulatory role, from which it introduces market-like incentives and management structures that apply to both public and private sector providers alike, and which tend to be reimbursed based on measures of effective performance and/or citizen choice of provider. ${ }^{2,3}$

The post-2008 economic crisis in Europe has further reinforced this shift in direction, highlighting a new situation in which the earlier type of state or public sector predominance is increasingly less financially or institutionally sustainable. ${ }^{4-6}$ As part of this changed state role, it also has become necessary to re-assess the appropriate role for elected politicians, and to re-calibrate broad governmental strategies of governance and stewardship to better reflect day-to-day operational decisionmaking in what has become an organizationally more diverse provider environment. ${ }^{7}$

Embedded within this core organizing dilemma have been continual concerns about quality, responsiveness, and, in some contexts, access, regarding wholly publicly operated service providers. In both primary care and hospital sectors, public command and control structures of organization have lagged (sometimes dramatically) behind patient and citizen expectations. ${ }^{8-10}$ Reasons for this less-than-optimal behavior have been complex and intertwined. ${ }^{11}$ While specific problems are often closely tied to national context and cultural characteristics, other important factors frequently include (1) the difficulty of maintaining consistently executed and timely

Full list of authors' affiliations is available at the end of the article. 
capital investment in new equipment and/or procedures; (2) a demonstrated lack of innovative and or entrepreneurial clinical initiatives; (3) poor incentives embedded in fixed salary and work rule arrangements reflecting politically powerful yet risk-adverse public sector employee unions; and (4) erratic and often politically short-term interference in meso level institutional management by (depending on the country) elected national/regional/local political actors as well as, where the national government plays an operational role, senior Ministry staff. ${ }^{12-19}$

This article will examine key dimensions of how effectively this new strategic approach to governing health providers has been applied in two tax-funded European health systems; in both cases, the changing nature of the state's role is highlighted, and the complexity involved in changing governance strategies is explored. The next section frames the current governance debate in terms of the practical structural alternatives that policy-makers have to choose from by presenting two case studies: primary care in Sweden and hospitals in Spain. By exploring new patterns for two different subsectors of taxbased provider systems, the article provides a broader view of the process of structural change that is currently underway. The article finishes by observing that good governance cannot be reduced to a set of arbitrary bureaucratic rules but rather needs to be grounded in the day to day operational level if it is to have the desired effect on health sector reform outcome. Two caveats should be noted. The first is that, as already indicated, the paper does not focus on the financing side of health systems, nor on the different institutions that compose that part of the health system. While provider institutions certainly respond to the differing financial incentives that different types of funding structures may generate, and clearly those financial incentives influence the overall governance framework for these provider organizations, this paper limits itself to exploring the new structural and organizational models of service delivery institutions per se.

The second caveat is that this article explores these new models of provider side governance in the social, political, and cultural context of specifically European healthcare systems. It does not seek to compare European models with those found in other, quite different institutional and cultural contexts in for example OECD countries in North America or Asia. While such a comparison could shed interesting light upon the degree to which these tentative European models are innovative and successful, such a cross-cultural comparison is beyond the scope of this analysis at this stage.

\section{Framing the Governance Debate}

The concept of governance in health systems has had several different interpretations. It was first indirectly put forward in World Health Organization's (WHO's) World Health Report, published in 2000, which prescribed governance as the fundamental responsibility of national governments to steer their health systems in accordance with WHO's understanding of good levels of population health. ${ }^{20}$ Academic scholarship drew on broader political science models of governance, to include not just the stewardship responsibilities of duly constituted national, regional, and local government but also a wide range of actions by other non-governmental actors that influence the behavior and outcome of health system activity. ${ }^{21-23}$

Adapting this political science perspective, Duran et al ${ }^{24}$ point at the emergence of non-state actors who have a structurally important set of functions beside the formal organs of government that play a previously (but no longer) hegemonic role. They understand the definition of governance in the health sector as taking place at the three traditional levels of macro, meso, and micro. Macro would mostly consist of national-level policy-making functions, meso would consist of institutional-level decision-making functions, while micro would concern operational issues at the clinic or physician office level. All three levels are now rather blurred but at meso and micro levels, in particular, management as well as policy decisions become inexorably intertwined as part of institutional governance.

As a point of reference for the discussion below, the mesolevel definition of governance of hospitals is as follows:

"A set of processes and tools related to decision-making in steering the totality of institutional activity, influencing most major aspects of organizational behavior and recognizing the complex relationships between multiple stakeholders. Its scope ranges from normative values (equity, ethics) to access, quality, patient responsiveness, and patient safety dimensions. It also incorporates political, financial, managerial as well as daily operational issues." ${ }^{24}$

The definition of meso-level governance for large primary health centers would be similar in breadth, content and focus. In this paper, the analysis of governance focuses on the meso level, both inside specific hospitals - in Spain - and - in the Swedish case study - large primary health centers. By following two different types of care (hospital and primary care) in two quite different tax-funded healthcare systems, it becomes possible to identify some initial patterns where these governance arrangements are more adequate/successful and where they are less so.

Since 1990, the search for new "models" of meso-level provider governance in tax-funded European countries and also in Central European state-run hybrid social insurance systems has taken three different although structurally parallel directions. Each of these three provider model arrangements seeks to reduce the range and negative influence of the above-noted factors on provider performance, and to encourage higher standard, more responsive, accessible, and efficient medical services. Given that much of the distortion of performance noted earlier reflects the contradictory objectives inherent in the conflicting logics and rationalities of competing health sector power groups (physicians, patients, politicians, and employee unions), it is important to note that the core governance issue for these three new models cannot be to permanently resolve those conflicting lines of interest and authority, but rather to negotiate downward the more malign longer term consequences in each case.

Reform model/pattern \# 1 has sought to broaden the portfolio of policy options within the public sector itself. The core effort has been to develop new provider management strategies which, although operating under the state umbrella and within the regulatory structure of the governmental sector, would have a sufficient degree of independent decision-making so as to reduce the negative bureaucratic consequences of 
traditional governmental delivery. ${ }^{10,25}$ This approach has been adopted in the hospital sector in a number of countries including England, Norway, Portugal, and Spain with varying structural characteristics and with varying degrees of semiautonomous governance. ${ }^{1}$

Reform model/pattern \#2 for re-structuring governance of providers has been to reach outside the existing public sector to encourage the establishment of new private, mostly for-profit actors and entities, typically in primary and home care services but occasionally also in the hospital sector. This effort has occurred particularly in Sweden, Norway, Denmark, and also Finland. ${ }^{26,27}$ Also a number of different development strategies have been tested, including to a certain extent mixed private-public models with private finance but public ownership and regulatory oversight of operational management (Private Finance Initiative in England as well as the Alzira Model in Valencia).

Reform model/pattern \#3 combines reform models/patterns $\# 1$ and \#2 into a mixed public-private provider market. In this diverse pluralist approach, semi-autonomous public institutions compete for patients and/or contracts with new and/or existing privately owned providers. This third, mixed approach has been encouraged in hybrid tax and social health insurance systems in Central Europe including Estonia ${ }^{15}$ and Czech Republic, ${ }^{16}$ as well as in Israel's complex mix of public, not-for-profit private and for-profit private hospitals ${ }^{13}$ and somewhat less so in England.

Each of these three different approaches to re-structuring provider governance presents advantages and disadvantages, and each has had its difficulties in design, implementation, and in sustainability - this last particularly in preventing political authorities from seeking to re-exert direct control. A number of theoretical frameworks have been suggested for addressing these governance dilemmas. ${ }^{2,28-30}$

This configuration of new models is, however, curiously attenuated. The search thus far has focused on less politically constricted approaches inside the public sector, as well as on various types of openly profit-making private arrangements at the other end of the organizational spectrum. What thus far remains significantly under-developed in tax-funded European health systems is what previously existed in the middle of the spectrum - namely privately organized yet not-for-profit managed provider entities. These not-forprofit agencies typically reflect a wide variety of civil society elements, including religious, civic, community, employee, and also patient-based organizations, all founded and managed by non-state, non-governmental, non-public-sector actors. This middle range of provider institutions-based in private civil society organizations, although it once fulfilled a central role in most European countries in the form of mutual aid societies, religious-run hospitals and nursing homes, and other similar community-based organizations, ${ }^{31}$ no longer has a noticeable presence in predominantly tax-funded health systems, where the state and/or local governments have taken over nearly all of the service delivery functions. While some efforts have been made to resurrect this private non-profit sector in England, complicated present-day public sector contracting and procurement rules often militate against the ability of small non-profit organizations to participate successfully. ${ }^{32}$
In short, in addition to the three new governance models/ patterns discussed above, a (most likely supplemental) fourth one relying on the missing not-for-profit private institutions could help resolve some of the structural dilemmas that accompany either state operated institutions or forprofit private providers. At least in principle, non-profit organizations would help generate broader decision-making and policy participation across the society being served, greater transparency, clearer and more direct accountability to patients and citizens, and greater institutional flexibility and integrity. ${ }^{31,32}$ They also could introduce a higher level of pluralistic contestability, enabling patients to choose among different alternative provider systems that compete for patient custom to provide better quality and more timely care.

The ongoing experimentation with the three healthcare provider patterns detailed above, as well as the additional potential contribution of not-for-profit private actors, serves to underscore the extent to which health sector governance decisions in European health systems now extend beyond the role of formally constituted government alone. As suggested, to the degree that various private sector institutions are involved in stewardship and governance, these functions, in practice, have become shared zones of authority in which public sector government needs to accommodate the explicit expectations of private sector civil society actors in its own day-to-day behavior and activity.

Further, conversely, this symbiotic relationship between public and private sector governance roles raises a question as to whether government's overall legitimacy in the governance and stewardship of health systems has become to some extent dependent on the implied consent of civil society through its separate institutions and activities. ${ }^{33}$

This vision of a shared governance role leads to a second question, which is the focus of the two case studies in the next section of this paper: how best to operationalize such joint governance responsibilities in health system structures, and the degree to which recent experience in developing new provider models can point toward lessons and potentially more effective strategies in the future. Here it may be useful to point out that at the meso level of governance, the admixture of managerial decision-making with policytied issues of multiple stakeholders results in two different types of performance indicators. While traditional, mostly macro-level concerns about equity and access remain valid at the meso level, a key meso-level focus is on the internal operational factors that actually produce and deliver services: the day-to-day efficiency and effectiveness of clinical teams, departments, and clinics, for example. The presentation of the two case studies that follow below emphasizes these structural and operational dimensions of this process of meso-level governance.

\section{Two Provider-Side Cases Studies}

The two case studies below illustrate the complexity involved in setting up and developing these new public and mixed public-private provider models. Although the Swedish and Spanish health systems differ on a range of important organizational, social, and cultural parameters, they were selected because they each in their own way illustrate the multi-faceted nature of the operational reforms that tax- 
funded health systems in Europe are attempting to achieve, and the difficult governance issues that arise despite governments of different political perspectives introducing reforms with the best of intentions. The first case considers Sweden's experience with broadening a publicly operated set of primary health centers into a diverse set of differently configured and differently owned service providers. ${ }^{34}$ The second case reviews Spanish attempts to re-configure public hospital governance into several variants of semiautonomous decision-making arrangements. ${ }^{12}$ Despite contrasting in formal structure, the two cases reinforce each other by demonstrating the degree of complexity involved in re-configuring how meso-level governance is conceived and executed in contemporary healthcare systems ${ }^{[1-3]}$.

\section{A. Diversifying Primary Care Provision in Sweden \\ A.1. Background}

In Sweden today, the 21 counties (including 3 larger regions) own, operate, and (via county taxes) provide the predominant share of funding for an extensive network of public primary healthcare centers as well as district, tertiary, and university hospitals. Primary care physicians in Sweden (like Swedish hospital physicians) are unionized employees of the county council where they work, different from private primary care general practitioners in Denmark, Norway, and England, as well as in continental social insurance-based health systems, including many Central European countries as well. Sweden's 289 municipal governments, since Parliament's passage of the 1992 ADEL ("Elderly") Reform, are responsible for public nursing homes as well as home care services. The national government's health sector responsibility is exercised through broadly-written "frame" legislation as well as through a number of national agencies including the National Board of Health and Welfare and several ongoing statistical surveys which assess service quality and outcomes. ${ }^{35}$

The Swedish state's role in structuring primary care services extends back to the late 1700s, when King Gustaf III granted royal commissions to primary care doctors who agreed to see all patients in their area who needed care. ${ }^{36,37}$ In 1955, a national health insurance system was introduced that covered all office-based visits for Swedish citizens, and in 1973 the Parliament passed a primary care act that encouraged the then-26 elected county councils to establish public primary health centers to provide comprehensive care to their entire population. ${ }^{38}$

By the mid-1980s, the effort to construct a fully public primary care system, built up around large primary health centers staffed by physicians, nurses, health educators, and social workers, had become controversial. On the one hand, these health centers performed well when assessed in terms of aggregate population-based measures. ${ }^{39}$ They provided good quality clinical services to the Swedish citizenry, and the system's comprehensive character had generated substantial improvements in overall population health. ${ }^{40}$

On the other hand, however, this public clinic model also had a number of dysfunctional dimensions. ${ }^{41}$ It could be difficult to see the same physician on a subsequent visit, reducing continuity of care especially for chronically ill elderly. Scheduled appointments often required two week waiting times. Primary care clinics were only open Monday-Friday during regular business hours - when many patients had to be at work themselves. Citizens were forced by catchment areas to receive care at an assigned primary care center near their residence. There also were numerous bureaucratic obstacles to obtaining care, for instance telephone access hours were tightly restricted, typically to only one hour in the morning. In 1991, a newly elected center-right national government introduced the Huslakare Act, which enabled citizens to sign up with one primary care doctor working in their publicly operated primary health center, creating an individual patientdoctor relationship inside the publicly operated primary care system. ${ }^{42}$ Then Minister of Health Bo Könberg believed that such a "house doctor" system would improve continuity of care and patient compliance, enhance quality of care, and thus improve clinical outcomes. It also would improve the publicly operated medical system's responsiveness to patients and thus patient satisfaction. While several counties chose to introduce aspects of this approach, a number of county councils were resistant to it.

There also were structural problems in its implementation. Swedish public primary care physicians worked only 40 hours per week (in contrast to private primary care doctors who often work 50 or more hours per week), and, further, were often not available to see patients due to continuing education courses and collaborative work with schools, nursing homes, and other social welfare institutions. Thus patients sometimes had to see other physicians when they needed an appointment, reducing the continuity of care that the new model was intended to provide. This problem was especially problematic for the large and growing number of elderly in Sweden, many with one or more chronic conditions whose treatment relied on regular visits, and who often found themselves still having to explain their condition again to a new and unfamiliar doctor.

In 1995, after the return of a Social Democratic government, Parliament withdrew the enabling legislation. Several counties, however, chose to keep the changed arrangements already in place, and even to continue further implementation. ${ }^{35,43}$

\section{A.2. The Current Reform}

Starting in 2007, five separate county councils sought to strengthen their primary care system by introducing increased patient choice of private as well as publicly managed primary care providers, ${ }^{40}$ adopting an organizational approach that was broadly consistent with Reform model/pattern \#3 above. In 2010, a subsequent center-right government systematized this process through national legislation which required that all of the now- 21 county councils (several having merged into regional bodies) allow private primary care practices to be established, and fund those practices on a contract basis, tied to the number of patients they saw. ${ }^{34,40}$ This Act on System of Choice in the Public Sector (in Swedish, Lag on Valfrihetssystem, LOV) was implemented on January 1, 2010. Unlike the unsuccessful reform in the early 1990s, however, the new law had to be more flexible, since different counties had already introduced somewhat different arrangements. Moreover, the individual's right to choose was to select their health center, rather than an individual physician. ${ }^{35}$ This helped sidestep some of the organizational dilemmas that the prior reform had faced. 
Eight months after the national reform was implemented, an overall total of 223 new primary care centers had been established across all Swedish counties as a result of the reform process, representing an increase of $23 \%$ in the total number of facilities. ${ }^{44}$ Anell ${ }^{40}$ reports that the total number of primary care providers has increased by $20 \%$, with more private providers being established in Sweden's three large urban conurbations. A study in 2012 of available statistics found that a full $50 \%$ of all primary care visits in Sweden took place in non-public practices. ${ }^{45}$

There also have been several academic studies which indicate that the number of people who have taken contact with primary care doctors has increased, ${ }^{46}$ with a higher proportion of the increase in urban areas and among individuals with above average incomes. ${ }^{40}$ Thus far, there is little indication that overall quality of primary care services has changed. ${ }^{40}$ Despite the rapid roll-out of the national reform, however, this major organizational shift was accompanied by several structural problems. These reflected the fact that the national government had not written into the legislation restrictions on the type of private entity that could own and/or operate these new primary care practices.

As the process went forward, several unexpected developments occurred. The first was that fewer publicly employed primary care doctors than anticipated took the leap of leaving public employment to set up their own private practice. Unwilling to exchange their existing income security for a business loan from a bank, some existing primary care doctors chose not to set up their own practices (Calltorp J, oral communication, August 2013).

In turn, this opened the private primary care field to two particular types of private sector competitors. The first was the relatively small number of existing private primary care doctors established within Praktikertjanst, a private notfor-profit cooperative that helped private physicians run their practices and provided them with pension-related arrangements. The second was private for-profit firms, including "risk-capital" funds, that saw the new structure of private primary care as a good investment opportunity (Calltorp J, oral communication, August 2013)..$^{35,40}$ The dilemma has been that these risk-capitals funds commit to building up primary care practices, but only in order to sell them at a profit within the funds' usual 5-year window to repay their investors. Moreover, these risk-capital funds are themselves not regulated by the public sector, as they do not issue stock and are not listed on the (publicly regulated) Swedish stock exchange (Calltorp J, oral communication, August 2013). Thus some of the new private sector owners of primary care practices are not committed to the type of stable long-term management that has been shown to enhance the quality of primary care. ${ }^{47}$

\section{A.3. Implications for Health Sector Governance}

Looking back at these developments, it is valuable to consider how the overall structure of meso-level governance changed in Swedish primary care as a result of this structural reform. The intentional actions of the five initial county governments and then of the national government in instituting compulsory legislation for all counties and regions served to introduce a new, separate, and, while still governmentally regulated, more independent form of decision-making in these newly established private primary health centers. As the definition of meso-level governance above suggests, authority became shared between government and non-governmental actors, with substantial areas of decision-making leaving public sector hands. As a result, decisions that had clear overall governance implications - where to locate new primary care centers, for example, or whether to utilize a less-transparent form of ownership (risk-capital) or not - moved outside of formal government into various types of civil society (eg, non-public) entities and actors.

The results of this shift in meso-level governance responsibility appear in a variety of places, including the research results finding that more urban than rural centers were opened as part of the reform, and that proportionally more aboveaverage income individuals utilized these new structures. While the equity dimensions of these location decisions would require additional analysis (primary care in some fastgrowing urban areas has been less available than in other fixed or shrinking population rural areas), meso-level governance decisions have clearly had policy as well as managerial implications as a result of the changed ownership and/or management structure for primary health centers. While this shared approach to governance raises questions about ceding democratic levers of control in terms of traditional Swedish welfare state norms, ${ }^{48,49}$ the shared action of multiple public and private actors as part of welfare state services can also be viewed as expanding rather than contracting society's zone of democratic action. ${ }^{50}$

Overall, it would appear that the Swedish national government's role in the governance process around the 2010 System of Choice reform of primary care had several quite different dimensions. On the positive side, it achieved its objective of diversifying the supply of primary care services, and established individual choice of type of provider as a normal part of Swedish life. For those who believe that continuity of care and individual choice are essential to effective primary care, then the stewardship element of the governance equation was reflected in improved quality of services.

On the less positive side, however, the emergence of some new primary care owners who lack normal accountability standards, and may also lack transparency regarding their objectives and strategy, raises a different side of the governance equation. Academics may debate whether the lack of accountability and transparency was necessary to achieve the improvement in terms of choice and continuity. Many politicians, however, would not be surprised at the governance tradeoffs that rapid change in service providers appeared to require..$^{51}$

\section{B. Establishing Semi-autonomous Hospitals in Spain B.1. Introduction}

Spain was transformed from an authoritarian, centralist regime to a democratic 'federal-like system without federation' state, when power over a number of policy sectors including health was devolved by the 1978 Constitution to 17 regional governments (Comunidades Autónomas). ${ }^{52}$ All public health resources were merged into a tax-funded Sistema Nacional de Salud (SNS) offering universal coverage to all residents. ${ }^{53}$ 
Given the legal and programmatic constraints on hospitals remaining from the Franco era (which ended in 1975), the development of semi-autonomous hospitals in Spain was a remarkable event. The new hospital models resembled those introduced elsewhere in Europe, seeking health providers' autonomization, corporatization and, in some cases, privatization, while accommodating national culture and the political as well as legal context. ${ }^{54}$ Influenced by the New Public Management paradigm, ${ }^{2}$ a mix of national policymakers, civil servants and managers within the new SNS sought to modernize hospital activities, albeit with limited strategic vision and political support..$^{55}$

Semi-autonomous hospitals were first sponsored in the mid1990s by the ruling Socialist Party in Andalucia. Over the next several years the initiative was - remarkably - accepted by virtually all other political forces. Slowly a spectrum of four hospital governance "models" (originally five) was created with different degrees of autonomy - for more details see. ${ }^{12}$

Public Health Enterprises (Empresas Públicas Sanitarias, EPS): Staff are non-statutory instead of civil servants, with clinicians under a performance-related payment scheme. There remained substantial political intervention, however, as the regional health minister chaired the Supervisory Board. Hospitals in EPS model: in Andalucía: Costa del Sol Marbella, Poniente, Alto Guadalquivir and Empresa de Emergencias Sanitarias; in Madrid: Fuenlabrada.

Foundations (Fundaciones, F): Not-for-profit organisations regulated by private law and with greater capacity to decide on the basket of services they provide and autonomy to choose where to invest and whether to rent or buy equipment. They are also free to manage their own cash-flow and to pay their providers directly, which allows them to negotiate better deals. Professional staff are non-statutory (eg, not civil servants). Hospitals in $F$ model: In Madrid: Alcorcón; in Baleares: Manacor; in Galicia: Barbanza, Virxe da Xunqueira, Verín and Salnés (status abolished in July 2008). A shortliving variety of Fundaciones (now de facto abolished) were Public Health Foundations (Fundaciones Públicas Sanitarias, FPS), staffed by statutory personnel.

Consortium (Consorcios, C): Legal entities resulting from merging resources from more than one public authority, usually the regional government and a lower local one. Staff are not statutory employees and hospital management typically enjoys autonomy to rent or buy equipment as well as to decide on the basket of services to offer, often supplementing a public basket with extra services (usually restricted to ambulatory care) provided to public patients covered by private health insurance and fully private patients. Hospitals in $C$ model: In Catalonia: Maresme, Integral de Catalunya, Vic and Tarrasa; in Sevilla: Aljarafe -San Juan de Dios.

Administrative Concessions (Concesiones Administrativas, $C A$ ): A private concessionary company - usually a joint venture between private health insurers, health groups, building societies, or banks - receives a tender to build a hospital and - in contrast to the Private Finance Initiative (PFI) model in England - to manage it as well, including providing clinical and non-clinical services, usually with non-statutory staff. However in the Hospital de la Ribera in Alzira, the existing statutory staff was given a choice on whether or not to convert to non-statutory status - and its most important feature (capitated funding models jointly for hospital and primary care) had a serendipitous origin and was not part of any purposeful design. One controversial aspect of CAs is whether the company itself should keep any eventual surpluses/profits or whether some or all should be repaid to the regional department of health. Hospitals in CA model: In Valencia: Ribera Hospital in Alzira, Torrevieja; Marina Alta in Denia and Manises; in Madrid: Infanta Elena in Valdemoro. The Instituto para el Desarrollo e Integración de la Sanidad (IDIS), a well-known think tank of the Spanish private health sector, presents the CA model in its 2015 Report as the answer to the current public sector funding shortage, able to provide the highest quality standards with lower expenditure levels. The report, however, also acknowledges the continuation of innovative public-private partnership (PPP) experiences in Murcia, Baleares, Cataluña, and Galicia among public hospitals and health technology enterprises. ${ }^{56}$

Administrative Concessions concentrate in Madrid and Comunidad Valenciana where currently there are 10 facilities under the CA model (all hospitals plus also a central lab), as below (Tables 1 and 2).

All together, the autonomy of the self-governed hospital "models" can be placed on a continuum, measured from less to more autonomous (from the EPS to the F, then the $\mathrm{C}$ and finally the CA).

All new models have been applied in particular to newlybuilt public hospitals, freeing the initiatives from inherited constraints and reducing opposition from trade unions. The changes affected a number of essential areas and the corresponding tools to better govern the facility:

a. Financial arrangements including decisions on capital investments, operating expenses (budgets and capacity to find additional sources of revenue), ability to incur debt, arrange loans and retain surpluses.

b. Constraints in running operations, such as setting contracts, terms and conditions of hiring and firing staff; market segmentation and product and service specialization (eg, waiting time management).

Table 1. Facilities Under the CA Model in Madrid

\begin{tabular}{lcc}
\hline Facility & No. of Beds & Year \\
\hline Hospital Infanta Elena & 117 & 2007 \\
Central Lab - Madrid Region & - & 2010 \\
Hospital de Torrejón & 250 & 2011 \\
Hospital de Móstoles & 310 & 2012 \\
Hospital Collado Villalba & 140 & 2014 \\
\hline
\end{tabular}

Abbreviation: CA, Concesiones Administrativas.

Table 2. Facilities Under the CA Model in Comunidad Valenciana

\begin{tabular}{lcc}
\hline Facility & No. of beds & Year \\
\hline Hospital de La Ribera & 301 & 1999 \\
Hospital de Denia & 266 & 2006 \\
Hospital de Torrevieja & 277 & 2006 \\
Hospital de Manises & 354 & 2009 \\
Hospital Vinalopó & 230 & 2010 \\
\hline
\end{tabular}

Abbreviation: CA, Concesiones Administrativas. 
c. Institutional arrangements such as the legal, social, financial, and political status of the hospital, including role, freedom from political interference in making decisions (on services, incentives/sanctions), size and composition of different boards, etc. as well as the relationships with stakeholders (authorities, professional organizations, unions) and accountability arrangements related to supervision (reporting obligations in terms of transparency, content, and timing), citizen and patient involvement.

\section{B.2. Assessing the Evolution of Different Spanish Models}

For all practical purposes, no publicly owned hospital was, or can ever expect to be, fully autonomous. The real-world issue for hospital governance strategies in the public sector necessarily becomes the "degree of autonomy," and over which factors of institutional life. The most that public hospitals can aspire to is to be acknowledged as semi-autonomous, having a limited degree of institutional independence within clearly defined but rigorously enforced decision-making boundaries (although these can be changed by subsequently elected politicians).

Some of the innovative features of the Spanish semiautonomous models have since been eroded by strong centralizing political forces, starting with the 2007 Law on Public Sector Contracts which explicitly reduced the autonomy of those schemes.

The political polarization of the country following the economic crisis of 2008 has further changed the policy environment, ${ }^{57}$ leading to questions about the sustainability of the publicly run health system. The deepening of the pro-privatization movement in the conservative camp (placing new hospitals under private law in several regions) accompanied by a stepping back towards traditional forms of governance in the socialist camp (presenting virtually any alternative arrangement as hidden privatization) deepened this divide.

One notable manifestation of polarization has been the absence of impartial evaluation efforts. There have been remarkably few studies on the relative performance of centrally managed hospitals vis-à-vis each of these innovative models or among them (it is obvious that the information most often exists, but it is not being made public). Publicprivate mix experiences are being therefore vehemently discussed in Spain almost without any available study to assess the performance of the new centers. ${ }^{58}$ The report "Los Servicios Sanitarios de las CCAA. Informe 2015 (XII Informe) Septiembre 2015" - Regional Health Services, XII Report, September for example, has been issued with data from public documentation, published by the Spanish Ministry of Health; National Institute of Statistics; Centre of Sociological Research; and other public institutions. This is a periodical report that researches differences and inequalities among the way Spanish citizens are cared for in different parts of the country. The above-cited September 2015 issue deplores the fact that access to public health system functioning related data remains in practice "almost impossible" to obtain not only for citizens and researchers, but also for international institutions (mention is made that, for Spain, OECD Health Data 2015 only provides 2012 data) despite governments commitment to introduce "transparency" - even through a law. ${ }^{59}$

In the absence of true comparative figures, supporters of new governance arrangements emphasise their higher efficiency in using resources (beds) and in maximising the use of ambulatory care alternatives, with an average cost per unit of production that is $30 \%$ lower and adjusted human resources activity that is $37 \%$ higher. ${ }^{60}$ This finding is hardly surprising, however, given that new not-bigger-than-300beds hospitals tend to be smaller in size and staff numbers (and have a simpler case mix) than hospitals under traditional management. In addition, an English National Health Service (NHS) Confederation study trip to the Hospital de la Ribera in Alzira in 2011 assessed its performance positively (using limited data provided by the hospital, and comparing these to that of the Valencia region hospitals under traditional management). Alzira had higher patient satisfaction rates, lower staff absenteeism numbers, shorter average lengths of stay, lower waiting times and lower capitation costs. ${ }^{61}$

Notably, even less autonomous models of hospital governance, like the EPS, seem to achieve some positive results when compared with traditional management models. In Andalucia, the parliamentary auditing body compared an EPS (348 beds and a population of 373000 ) with a 555-bed hospital (providing services to 349000 people) and concluded that the former had lower operational costs and staff absenteeism. ${ }^{62}$ From the other side, critics claim that costs are much higher in CAs or PFI hospitals than in public managed hospitals. A study by the largest health trade union in Madrid argued that a CA or PFI bed costs $€ 1660$ per day, while in a public hospital the daily cost is $€ 955 .{ }^{63}$ One of the few technically sound evaluations concluded that, in general, no overwhelming superiority of any model has been proven across all measures and that each legal form probably has specific advantages and disadvantages. ${ }^{64}$

In this context, taking advantage of the economic crisis, a strong process of concentration of private hospitals by means of mergers and acquisitions started in Spain in 2012 - in a rather atomized sector where in 2011, the five biggest groups represented only $31 \%$ of the private market, compared to $64 \%$ in United Kingdom and 89\% in Germany. ${ }^{56}$ Private hospitals in Spain own 33\% of beds but represent 53\% of centres, with biggest presence in Cataluña, Madrid, and Andalucía. They are grouped into three clusters: independent hospitals and clinics (58\% of mostly small hospitals and $46 \%$ of beds); hospital groups devoted to managing hospitals (37\% of hospitals and $50 \%$ of beds); and hospitals belonging to private health insurance companies ( $4 \%$ of hospitals and $4 \%$ of beds). Concentration is explicitly understood as an unstoppable movement that "answers pressures for change but at the same time, and contrary to what would be expected, does not prevent the entry of new actors." The health sector is believed to have to get used to "the arrival of concentration processes as well as to the entrance of new actors." 65

\section{Concluding Observations}

The search for new governance models for providers both inside and beyond the public sector, and in primary as well as hospital care, speaks to a growing worry about the resilience and sustainability of current provider arrangements generally. 
In particular, concern has been voiced that the current historically inherited hospital model - in both structural and administrative terms - may not be sustainable and/or will be subject to unprecedented change. ${ }^{66,67}$

Part of this problem reflects insufficient resources to confront increasing demand for more sophisticated providers, especially in the context of weak national economies. As noted earlier, the desire for tight control by political actors as against pressure from both patients and clinical staff for greater quality and responsiveness creates an inherent clash of organizational objectives. A related issue is the resistance of some public providers to adopt technology-related possibilities - not only machines but also organizational arrangements, with specific emphasis concerning how services are configured and delivered given the limited availability of professional health managers. ${ }^{68}$

Several conclusions can be outlined regarding the advantages and disadvantages of the new governance models discussed above. As the examples from Spain illustrate, the creation of semi-autonomous hospitals triggered a series of policy clashes that were resolved in a rather non-explicit manner. However evidence also abounds that the development of semi-autonomous public hospital models, although typically established by last-minute, ad hoc, politically driven legislation, was genuinely meant to improve efficiency while overcoming the rigidity of the inherited hospital governance model. These publicly owned hospitals were given a broad spectrum of configurations, institutional autonomy and at least a moderate degree of internal and external market incentives, demonstrating that innovative governance arrangements do not necessarily require extensive long-term planning.

Viewed at a broader European level, semi-autonomous hospital models similar to those adopted in Spain are now seen as reasonably successful in a number of countries. ${ }^{1}$ These more flexible governance models are popular with patients and, although they are not innovative in everything they do, many have considerable discretion in such areas as financial incentives, hiring and firing, and patient responsiveness and satisfaction. Some also have input in capital development as well as the ability to retain their budget surplus for use in the next budget year, and many no longer run annual deficits.

In primary care, recent Swedish experience suggests a continued need to identify a governance strategy that can better combine universal coverage with individually acceptable levels of attention and care. Similarly strong reform pressures on the (somewhat different) public health center model of primary care in Finland ${ }^{69}$ imply that a new governance approach may be needed for health center-based primary care arrangements generally.

A key unanswered question is the impact of different reform models on the long-term capacity of non-state and particularly non-profit provider institutions. In the Swedish primary care case, building non-state capacity was an explicit goal of the legislation and of its implementation. In the Spanish hospitals case, the growth of civil society capacity and institutions was a secondary, peripheral, and mostly unintentional objective. This difference suggests that the outcomes of these new governance initiatives may vary considerably in how they impact the overall balance between various types of public and private sector providers.

Beyond the noise of political battles, it is hard to foresee any concerted move to abolish these new models. Indeed, some models are explicitly seen as a transitory stepping stone towards a future delivery structure of which the "only known thing" is that it will differ considerably from the institutions of today. ${ }^{70}$

The continuing evolution of organizational models in both the Swedish and Spanish provider cases highlights, however, the degree to which the future of provider governance in taxfunded European health systems will likely be shaped by the interface a variety of different conceptual approaches and political experiences at country ground level.

\section{Acknowledgements}

The authors would like to thank the journal's anonymous reviewers for valuable comments and suggestions on a prior version of this article.

\section{Ethical issues}

Not applicable.

\section{Competing interests}

The authors affirm that they have no financial or professional conflicts of interest concerning any of the organizations or information discussed in this paper.

\section{Authors' contributions}

Both authors were equally involved in developing the concepts and finalizing the text of this article.

\section{Authors' affiliations}

${ }^{1}$ Department of Health Policy and Management, Rollins School of Public Health, Emory University, Atlanta, GA, USA. ${ }^{2}$ AllDMHealth, Seville, Spain.

\section{Endnotes}

${ }^{[1]} \mathrm{A}$ note on methods. The information presented in the Swedish case study reflects field research in Sweden in the early 1980 s by RBS, including qualitative research projects inside provider institutions and extensive interviews with political decision-makers at the institutional, county, and national levels. This was followed by an extended research project on the processes and outcomes of Swedish health system reform conducted jointly with Professor Casten von Otter at the Swedish Center for Working Life in Stockholm from 1986-1995. Subsequently RBS co-edited and wrote the final assessment chapter for a 2009 European Observatory volume on Nordic health reform.

${ }^{[2]}$ The information presented in the Spanish case study reflects extensive research, management, and consulting work conducted over 30 years by AD, which crystallized in the writing of the two volumes of "Health in Transition" series on Spain (2006 and 2010, the first as leading author and the second one as co-author) of the European Observatory on Health Systems and Policies, Brussels, as well as a 2011 review with Arturo Alvarez on the structure of health reform in Spanish hospitals, published in a 2011 volume on public hospital governance.

${ }^{[3}$ References to both the Swedish and Spanish research just noted are provided in the text and in the bibliography at the end of this article. Additional references from other publications for specific aspects of both the Swedish and Spanish cases are cited in the text and referenced in the bibliography.

\section{References}

1. Saltman RB, Duran A, Dubois HFW, eds. Governing Public Hospitals: Recent Strategies and the Movement Toward Institutional Autonomy. Brussels: European Observatory on Systems and Policies; 2011.

2. Hood C. A public management for all seasons. Public Adm. 1991;69(1):3-19. doi:10.1111/j.1467-9299.1991.tb00779.x

3. Gingrich JR. Making Markets in the Welfare State: The Politics of 
Varying Market Reforms. Cambridge, UK: Cambridge University Press; 2011.

4. Saltman RB, Cahn Z. Re-structuring health systems for an era of prolonged austerity. BMJ 2013;346:f3972. doi:10.1136/bmj. f3972

5. Thomson S, Figueras J, Evetovits T, et al. Economic crisis, health systems, and health in Europe: Impact and implications for policy. Brussels: European Observatory on Health Systems and Policies; 2014.

6. Duran A, Jeurissen P, Saltman R. Uncomfortable Realities: Making Real Change Inside Real Institutions in a Consolidating Hospital Sector. BMC Health Serv Res. Special Issue 'Medicine and Management in European Hospitals', Kirkpatrick I, Kuhlmann E, Hartley K, Lega F, eds. In press

7. Duran A, Saltman R. Governing public hospitals. In: Blank R, Kuhlmann E, Bourgeault IL, Wendt C, eds. International Handbook of Healthcare Policy and Governance. Basingstoke, UK: Palgrave MacMillan; 2015:443-461.

8. Coulter A. Engaging Patients in Health Care. Maidenhead, UK: Open University Press; 2011.

9. Winblad $U$, Ringard A. Meeting rising public expectations: The changing roles of patients and citizens. In: Magnussen J, Vrangback K, SaltmanRB, eds. Nordic Health Care Systems: Recent Reforms and Current Policy Challenges. Maidenhead, UK: Open University Press/McGraw-Hill Education; 2009:126150.

10. Saltman RB, von Otter C. Planned Markets and Public Competition: Strategic Reform in Northern European Health Systems. "State of Health" Series. Buckingham, UK: Open University Press; 1992.

11. Saltman RB, Busse R. Balancing regulation and entrepreneurialism in Europe's health sector: theory and practice. In: Saltman RB, Busse R, Mossialos E, eds. Regulating Entrepreneurial Behavior in European Health Care Systems. European Observatory on Health Care Systems series. Buckingham, UK: Open University Press; 2002:3-52.

12. Alvarez A, Duran A. Hospital governance in Spain. In: Saltman, RB, Duran A, Dubois HWF, eds. Governing Public Hospitals: Recent Strategies and the Movement Toward Institutional Autonomy. Brussels: European Observatory on Systems and Policies; 2011:241-260.

13. Chinitz D. Hospital Governance in Israel. In: Saltman RB, Duran A, Dubois HWF, eds. Governing Public Hospitals: Recent Strategies and the Movement Toward Institutional Autonomy. Brussels: European Observatory on Systems and Policies; 2011:163-178.

14. Edwards N. England. In: Saltman RB, Duran A, Dubois HWF, eds. Governing Public Hospitals: Recent Strategies and the Movement Toward Institutional Autonomy. Brussels: European Observatory on Systems and Policies; 2011:113-140.

15. Habitch T, Habitch J, Jesse M. Hospital Governance in Estonia. In: Saltman RB, Duran A, Dubois HWF, eds. Governing Public Hospitals: Recent Strategies and the Movement Toward Institutional Autonomy. Brussels: European Observatory on Systems and Policies; 2011:141-162.

16. Roubal T, Hrobon P. Czech Republic. In: Saltman RB, Duran A, Dubois HWF, eds. Governing Public Hospitals: Recent Strategies and the Movement Toward Institutional Autonomy. Brussels: European Observatory on Systems and Policies; 2011:99-112.

17. Magnussen J. Norway. In: Saltman RB, Duran A, Dubois HWF, eds. Governing Public Hospitals: Recent Strategies and the Movement Toward Institutional Autonomy. Brussels: European Observatory on Systems and Policies; 2011: 201-216.

18. Hagen TP, Vrangbaek K. The changing political governance structures of Nordic health care systems. In: Magnussen J, Vrangback K, Saltman RB, eds. Nordic Health Care Systems:
Recent Reforms and Current Policy Challenges. Maidenhead, UK: Open University Press/McGraw-Hill Education; 2009:107125.

19. Vrangbaek K. The political process of restructuring Nordic health care systems. In: Magnussen J, Vrangback K, Saltman RB, eds. Nordic Health Care Systems: Recent Reforms and Current Policy Challenges. Maidenhead, UK: Open University Press/ McGraw-Hill Education; 2009:53-77.

20. World Health Organization (WHO). World Health Report 2000: Health Systems: Improving Performance. Geneva: WHO; 2000.

21. Rhodes RAW. The new governance: governing without government. Polit Stud (Oxf). 1996;44(4):652-667. doi:10.1111/j.1467-9248.1996.tb01747.x

22. Stoker G. Public-private partnerships and urban governance. In: Pierre J, ed. Public-Private Partnerships in Europe and the United States. London: MacMillan; 1997:34-51.

23. van Doeveren $\mathrm{V}$. Re-thinking the meaning of governance and good governance. Paper presented at: Governing good and governing well: the first global dialogue on ethical and effective governance; 28-30 May, 2009; Amsterdam.

24. Duran A, Dubois HFW, Saltman RB. The evolving roles of hospitals and recent concepts of public sector governance. In: Saltman RB, Duran A, Dubois HWF, eds. Governing Public Hospitals: Recent Strategies and the Movement Toward Institutional Autonomy. Brussels: European Observatory on Systems and Policies; 2011:15-34.

25. LeGrand J, Bartlett W, eds. Quasi-markets and Social Policy. London: Macmillan; 1993.

26. Saltman RB, Vrangbaek K, Lehto J, Winblad U. Consolidating national authority in Nordic health systems. Eurohealth. 2012;18(3):21-25

27. Saltman RB, Teperi J. Health reform in Finland: Current proposals and unresolved challenges. Health Economics Policy and Law. 2016; forthcoming.

28. Rhodes RA. Understanding Governance: Policy Networks, Governance, Reflexivity and Accountability. Buckingham, UK: Open University Press; 1997.

29. Osborne D, Gaebler T. Re-inventing Government. Reading, MA: Addison-Wesley; 1992.

30. Kettl D. Sharing Power. Washington, DC: Brookings Institution; 1993.

31. Saltman RB, Dubois HFW. The historical and social base of social health insurance systems. In: Saltman RB, Busse $\mathrm{R}$, Figueras J. Social Health Insurance Systems in Western Europe. Maidenhead, UK: Open University Press/McGraw-Hill Education; 2004:21-32.

32. Mutuals Taskforce. Public Service Mutuals: The Next Steps. London: Department of Health; 2014.

33. De Roo AA. Contracting and solidarity: Market-oriented changes in Dutch health insurance schemes. In: Saltman RB, von Otter C, eds. Implementing Planned Markets in Health Care: Balancing Social and Economic Responsibility. "State of Health" Series. Buckingham, UK: Open University Press; 1995: 45-64.

34. Anell A. Choice and privatization in Swedish primary care. Health Economics, Policy and Law. 2011;6 (4):549-569. doi:10.1017/ s1744133110000216

35. Anell A, Glenngard AH, Merkur S. Sweden: Health System Review. Brussels: European Observatory on Health Systems and Policies; 2012.

36. Scott F. A History of Sweden. Minneapolis: University of Minnesota Press; 1957.

37. Serner U. Swedish Primary Health Care. In: Heidenheimer A, Elvander N, eds. The Shaping of the Swedish Health System. New York: St. Martin's Press; 1980.

38. Saltman RB. Health care in Sweden. In: Saltman RB, ed. International Handbook of Health Care Systems. Westport, CT: 


\section{Greenwood Press; 1988:285-294.}

39. Kringos $D$, Boerma $W$, Bourgueil $Y$, et al. The strength of primary care in Europe: an international comparative study. $\mathrm{Br} J$ Gen Pract. 2013. doi:10.3399/bjgp13X674422

40. Anell A. The public-private pendulum - Patient choice and equity in Sweden. N Engl J Med. 2015;372(1):1-4. doi:10.1056/ nejmp1411430

41. Saltman RB, von Otter C. Re-vitalizing public health care systems: a proposal for public competition in Sweden. Health Policy. 1987;7(1):21-40. doi:10.1016/0168-8510(87)90043-1

42. Krasnik A, Paulsen B. Reforming primary health care. In: Magnussen J, Vrangback K, Saltman RB, eds. Nordic Health Care Systems: Recent Reforms and Current Policy Challenges. Maidenhead, UK: Open University Press/McGraw-Hill Education; 2009:233-254.

43. Harrison M, Calltorp J. The re-orientation of market-oriented reforms in Swedish health-care. Health Policy. 2000;50(3):219240. doi:10.1016/s0168-8510(99)00060-3

44. Swedish Competition Authority. Uppföljning av vårdval $i$ primärvården-Valfrihet, mångfald och etableringsförutsättningar. Slutrapport (Study of privatization and choice in primary care. Final report). Stockholm: Konkurrensverket; 2010.

45. Andersson-Back M, Calltorp J, Saltman RB. Privatization in Swedish health care. Working paper, Swedish Forum on Health Policy, Stockholm; 2013.

46. Vårdanalys. Let the right one in - what impact have reforms in the pharmaceutical market, in primary care, and regarding the waiting-time guarantee had on patient access? Rapport 2014:3 [In Swedish].

47. Kringos D, Boerma W, van der Zee J, Groenewegen P. Europe's strong primary care systems are linked to better population health but also to higher health spending. Health Aff (Millwood). 2013;32(4):686-694. doi:10.1377/hlthaff.2012.1242

48. Bendz A. Providing welfare: The importance of public or private actors in welfare state regimes. In: 69th annual national conference, Midwest Political Science Association; Chicago; 2011.

49. Blomqvist P, Rothstein B. Velfardsstatens nya ansikte (The New Face of the Welfare State). Stockholm: Agora; 2015.

50. Saltman RB, von Otter C. Voice, choice, and the question of civil democracy in the Swedish welfare state. Economic and Industrial Democracy. 1989;10(2):195-209. doi:10.1177/0143831×89102004

51. Boerma WGW, Rico $A$. The changing conditions for structural reform in primary care. In: Saltman RB, Rico A, Boerma W, eds. Primary Care in the Driver's Seat? Organizational Reform in European Primary Care. Maidenhead, UK: Open University Press/McGraw-Hill Education; 2006:50-67.

52. Durán A. Health system decentralization in Spain: a complex balance. Euro Observer. 2011;13(1):7-10.

53. García Armesto S, Abadía B, Durán A, Bernal E. Health Systems in Transition - Spain: Health system review. Brussels: European Observatory on Health Systems and Policies; 2010:1-295.

54. Preker AS, Harding A. Innovations in health service delivery: the corporatization of public hospitals. Washington, DC: World Bank; 2003.

55. Belenes R. Un balance personal de 25 años de gestión sanitaria moderna en el Sistema Nacional de Salud (A personal balance of 25 years of modern health care management in the National Health System). Gaceta Sanitaria. 2003;17(2):150-156.

56. Instituto para el Desarrollo e Integración de la Sanidad (IDIS),
Sanidad Privada, Aportando Valor. Análisis de situación 2015. Madrid; 2015. https://www.fundacionidis.com/es/ informes/sanidad-privada-aportando-valor-an\%C3\%A1lisis-desituaci\%C3\%B3n-2015.

57. Alvarez A, Duran A. Spain's hospital autonomy: Muddling through the economic crisis. Eurohealth. 2013;19(1):8-11.

58. Cortès-Franch I, González López-Valcárcel B. Crisis económicofinanciera y salud en España. Evidencia y perspectivas. Informe SESPAS 2014 (The economic-financial crisis and health in Spain. Evidence and viewpoints. SESPAS Report 2014). Gac Sanit. 2014;28(S1):1-6

59. Federación de Asociaciones para la Defensa de la Sanidad Pública (FADSP). Los Servicios Sanitarios de las CCAA. Informe 2015 (XII Informe). http://www.fadsp.org/index.php/ sample-sites/manifiestos/1111-los-servicios-sanitarios-de-lasccaa-informe-2015-xii-informe. Published September 2015.

60. IASIST. Evaluación de Resultados de los Hospitales en España según su modelo de gestión. Barcelona: IASIST; 2012. http:// www.iasist.com/files/Modelos_de_gestion.pdf.

61. NHS Confederation. The search for low-cost integrated healthcare: The Alzira model - from the region of Valencia. Brussels: European Office; 2011.

62. Cámara de Cuentas. Análisis comparativo de la actividad realizada por dos hospitales del sistema sanitario público de Andalucía: Hospital Virgen de Valme y Hospital Costa del Sol. Seville: Cámara de Cuentas. http://www.ccuentas.es/files/ reports/complete/1332156441-oe-04-2009-def.pdf. published 2008.

63. CSIT. Informe Comparativo Coste/Eficiencia de la Gestión Pública y la Gestión Privada de la Sanidad en la Comunidad de Madrid. http://www.actasanitaria.com/fileset/file_sobre_ Informe_CSIT_57842.pdf. Published December 3, 2012.

64. Coduras A, del Llano Señarís J, Raigada González F, et al. Gestión de tres procesos asistenciales según persona jurídica hospitalaria. Madrid: SEDISA; 2008.

65. PricewaterhouseCoopers $(P w C)$. Ten hot issues in the Spanish Health Sector for 2013 (Avoiding that economic crisis becomes a public health crisis). https://www.pwc.es/es/publicaciones/ sector-publico/assets/diez-temas-candentes-sanidad-2013.pdf. Published 2013.

66. Joint Commission. Health care at the crossroads: guiding principles for the development of the hospital of the future. http://www.jointcommission.org/guiding_principles_for_the_ development_of_the_hospital_of_the_future_/. Published November 19, 2008.

67. Nolte E, Pitchforth E, Miani C, Mc Hugh S. The changing hospital landscape. An exploration of international experiences. Rand Europe; 2014.

68. Management Sciences for Health. An Urgent Call to Professionalize Leadership and Management in Health Care Worldwide, Occasional Papers No. 4. http://projects.msh.org/ projects/Ims/Documents/upload/Professionalize_Leadership. pdf. Published 2006.

69. Lehto J, Vrangbaek $\mathrm{K}$, Winblad $\mathrm{U}$. The reactions to macroeconomic crises in Nordic health system policies: Denmark, Finland and Sweden, 1980-2013. Health Economics Policy and Law. 2014;10(1):61-81. doi:10.1017/S1744133114000243

70. Rechel B, Wright S, Edwards N, Dowdeswell B, McKee M, eds. Investing in Hospitals of the Future. Maidenhead, UK: Open University Press/McGraw Hill Education; 2009. 